\title{
Kinetic Modeling of Dye Effluent Biodegradation by Pseudomonas Stutzeri
}

\author{
Natarajan Rajamohan \\ Dpt of Chemical Engineering, \\ Sohar University, Sohar, Sulatanate of Oman \\ natrajmohan@gmail.com
}

\author{
Manivasagan Rajasimman \\ Dpt of Chemical Engineering, \\ Annamalai University, Annamalai Nagar, India \\ simms@rediffmail.com
}

\begin{abstract}
Dye industry waste water is difficult to treat because of the presence of dyes with complex aromatic structure. In this research study, the biodegradation studies of dye effluent were performed utilizing Pseudomonas stutzeri in a controlled laboratory environment under anoxic conditions. The effects of operational parameters like initial $\mathrm{pH}$ of the effluent and initial Chemical Oxygen Demand (COD) of the effluent on percentage COD removal were studied. A biokinetic model is established giving the dependence of percentage COD removal on biomass concentration and initial COD of the effluent. The biokinetics of the COD removal was found to be first order with respect to both the microbial concentration and initial COD of the effluent. The optimal $\mathrm{pH}$ for better bacterial degradation was found to be 8.The specific degradation rate was found to be $0.1417 \mathrm{l} / \mathrm{g}$ Dry Cell Mass (DCM) h, at $320 \mathrm{C}$.
\end{abstract}

Keywords- Dye effluent degradation; biokinetics; anaerobic.

\section{INTRODUCTION}

Over $7 \times 10^{5}$ metric tons of synthetic dyes are produced world wide every year for dyeing and printing. A very small amount of dye in water $(10-50 \mathrm{mg} / \mathrm{l})$ is highly visible and affects the aesthetic merit, water transparency and gas solubility of water bodies, Dyeing units are found in most countries and their numbers have increased. These industries have shown a significant increase in the use of synthetic complex organic dyes as the coloring material. The annual world production of textiles is about 30 million tones requiring 700,000 tonnes of different dyes which causes considerable environmental pollution problems. Dyes include a broad spectrum of different chemical structures, primarily based on substituted aromatic and heterocyclic groups such as aromatic amine $\left(\mathrm{C}_{6} \mathrm{H}_{5}-\mathrm{NH}_{2}\right)$, which is a suspected carcinogen, phenyl $\left(\mathrm{C}_{6} \mathrm{H}_{5}-\mathrm{CH}_{2}\right)$ and naphthyl $\left(\mathrm{NO}_{2}-\mathrm{OH}\right)$, the only thing in common is their ability to absorb light in the visible region. The waste water from these industries are characterized by high alkalinity, biological oxygen demand, chemical oxygen demand, total dissolved solids and with dye concentrations usually less than 1 $\mathrm{g} / \mathrm{dm}^{3}[1]$. Color is the first contaminant to be recognized in wastewater and has to be removed before discharging in to water bodies or on land. The inefficiency in dyeing processes has resulted in $10-15 \%$ of unused dyestuff entering the wastewater directly. Color present in dye effluent gives a straightforward indication of water being polluted and discharge of this highly colored effluent can damage directly the receiving water. Furthermore, it is difficult to degrade the mixtures of the wastewater from the textile industry by conventional biological treatment processes, because their ratio of Biochemical Oxygen Demand (BOD)/Chemical Oxygen Demand (COD) is less than 0.3 [2].

The discharges of dye house wastewater into the environment is aesthetically displeasing, impede light penetration, damage the quality of the receiving streams and may be toxic to treatment processes, to food chain organisms and to aquatic life. The degradation of molecules of dyes in the environments by microorganisms is likely to be slow, which means that it is possible for high levels of dye to persist, and potentially accumulate. Due to the low biodegradability of dyes, conventional biological treatment processes are inefficient in treating dye wastewaters. In addition, numerous physical and chemical techniques such as flocculation combined with flotation, electro-flotation, flocculation with $\mathrm{Fe}(\mathrm{II}), \mathrm{Ca}(\mathrm{OH})_{2}$, membrane filtration, precipitation, ionexchange, Ozonation and Katox treatment method involving the usage of activated carbon and air mixtures were also used [3]. Even though some of the above mentioned methods are effective, most of them suffer from shortcomings such as excess usage of chemicals, sludge disposal, expensive operating cost, ineffective color reduction for sulfonated azo dyes and poor sensitivity towards shock load conditions. Biological decolonization is employed under either aerobic or anaerobic environment. A number of reports discourage the azo dye decolonization by microorganism under anaerobic conditions as it leads to the formation of corresponding aromatic amines. Even though their reductive cleavage is responsible for colour removal, the formation of aromatic amines is highly undesired as they are reported to be carcinogenic. In the presence of oxygen, aromatic amines can be degraded. Degradation of azo dyes has been studied under aerobic conditions using both pure and mixed microbial cultures. The restrictive environmental legislation, the ecological problem and the high cost of conventional technologies for dye house effluent treatment have resulted in the search of economically viable and technologically suitable wastewater treatment plants. Dye house effluents usually contain azodyes which are highly resistant to biological treatment and these dyes are considered to be recalcitrant xenobiotic compounds because of the presence of $\mathrm{N}=\mathrm{N}$ bonds 
and other possible groups, like the sulphonic group, which are tough to be degraded. It was reported that some anaerobic bacteria could biodegrade dyestuffs by azoreductase activity. However the effluent from biodegradation of dyestuffs could be toxic. Also, reverse coloration may take place when the degradation products are exposed to oxygen. [4]. Because of these above-mentioned problems, full-scale application of bacterial degradation is limited. Also, only few research works have been reported on the aerobic degradation of azo dyes. Therefore, a need exists to develop a novel treatment technology for textile dye effluent treatment to ensure environmental protection from these harmful pollutants. The effectiveness of microbial decolorization depends on the adaptability and the activity of selected microorganisms. Over the past decades, many microorganisms are capable of degrading azo dyes, including bacteria, fungi and yeast $[5,6]$. However, the low $\mathrm{pH}$ requirement for an optimum activity of the enzymes and the long hydraulic retention time for complete decolorization are the disadvantages of using fungi. In addition, they may inhibit the growth of other useful microorganisms. Thus, large-scale applications of fungal decolorization have been limited.

With the aforesaid details in the background, this investigation was aimed to study the feasibility of biodegradation of the dye house effluent by employing the bacterial strain Pseudomonas stutzeri under anoxic conditions. Also, the biokinetic pattern of COD removal of the effluent was studied and the kinetic constants were determined.

\section{MATERIALS AND METHODS}

\section{A. Dye house effluent}

The dye house effluent was collected from a dyeing unit situated in Tirupur region (Tamilnadu, India). The characteristics of the dye house effluent were COD-3200 mg 11, BOD-840 mg 1-1 and $\mathrm{pH} 8.2 \pm 0.1$ [7]. The colour of the effluent was dark red due to the presence of dyes. The effluent was refrigerated at $4^{\circ} \mathrm{C}$ and used without any preliminary treatment.

\section{B. Microorganism}

Pure bacterial strain Pseudomonas stutzeri (MTCC NO: 101) was purchased from Microbial type culture collection and gene Bank, Chandigarh, India. The strain was maintained in growth medium whose composition is agar- $15 \mathrm{~g}$, Beef extract$1 \mathrm{~g}$, Yeast extract-2g, peptone-5g, Sodium chloride-5g in 1 liter of distilled water. The cultures were growth in a controlled environment in a working temperature of $32^{\circ} \mathrm{C}$.

\section{Estimation of cell mass and COD of effluent with cell free supernatant}

Samples were withdrawn from the conical flasks and centrifuged at $13,000 \mathrm{rpm}$ for 5 minutes. With the clear supernatant obtained, COD was evaluated [7]. Similar procedures were also followed to evaluate the degradation potential of strains incubated for specified period of time. The initial COD removal data were used to find the microbial activity based on per $\mathrm{mg} / \mathrm{l}$ of COD removed per gram of Dry Cell Mass (DCM) per unit time. The DCM in suspension was determined after dehydration at $80^{\circ} \mathrm{C}$ to constant weight.
Control experiment was conducted in parallel with uninoculated flasks. The Pseudomonas stutzeri strain was added in predetermined proportion $(0.62 \mathrm{~g} \mathrm{DCM} / \mathrm{l})$ to the effluent along with the growth medium. In order to find the maximum COD removal percentage of the dye house effluent by the bacterial strains, a test solution containing $0.62 \mathrm{~g} \mathrm{DCM}$ per liter and the proportionate quantities of growth medium constituents, was incubated under static conditions at $32{ }^{\circ} \mathrm{C}$. The time courses of percentage COD reduction and effluent COD removal were observed and plotted. In order to find out the concentration of cell mass, a calibration curve was also prepared between the dry weight of cell mass and optical density of the broth at $540 \mathrm{~nm}$.

\section{Effect of $\mathrm{pH}$}

Stock culture of the selected bacterium, Pseudomonas stutzeri was prepared by growing a single colony in $100 \mathrm{ml}$ of growth medium in $500 \mathrm{ml}$ conical flasks for 3 days at $32{ }^{\circ} \mathrm{C}$ under static condition. An aliquot of $1 \mathrm{ml}$ of each bacterium was inoculated into a $500 \mathrm{ml}$ conical flask with $10 \mathrm{ml}$ of growth medium plus $100 \mathrm{ml}$ of dye house effluent. As $\mathrm{pH}$ is one of the controlling factors of bacterial activity, it is inevitable to study its influence on \% COD removal. The $\mathrm{pH}$ of the medium was adjusted $4,6,8,10,12$ with $1 \mathrm{M} \mathrm{HCl}$.

\section{RESULTS AND DISCUSSION}

\section{A. Effect of effluent $p H$}

Among the various process variables, $\mathrm{pH}$ play a vital role for the optimal activity of bacterial cultures and $\mathrm{pH}$ is an influencing factor for nutrient transport across the bacterial cell membrane [8]. To determine the optimal $\mathrm{pH}$ for the bacterial activity, a set of batch tests were conducted at different $\mathrm{pH}$. The highest COD removal percentage of $93 \%$ was achieved at $\mathrm{pH}=8$. Whereas acidic effluent environment $(\mathrm{pH}=4, \mathrm{pH}=6)$ reduced the activity of, Pseudomonas stutzeri producing $12 \%$ and $58 \%$ COD removal respectively. Similar inhibitory effect on $\%$ COD removal was achieved when the $\mathrm{pH}$ moved towards a more basic region (i.e. $\mathrm{pH}=10,12$ ). The influence of $\mathrm{pH}$ on the percentage COD removal is illustrated in Figure 1.

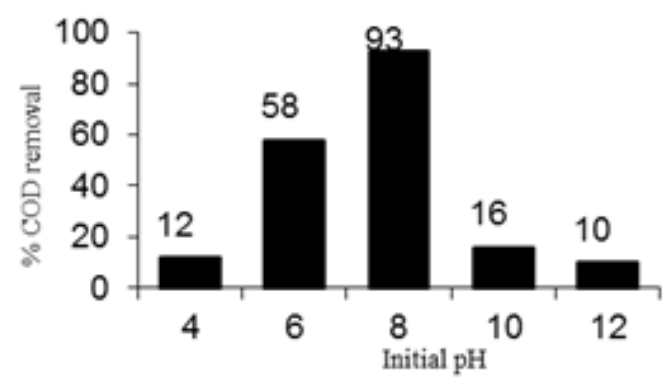

Fig. 1. Effect of solution $\mathrm{pH}$ on degradation of dye house effluent by Pseudomonas stutzeri $\left(\mathrm{t}=48 \mathrm{~h}\right.$; Temp $\left.=32{ }^{\circ} \mathrm{C} ; \mathrm{M}=0.62 \mathrm{~g} \mathrm{DCM}\right)$

The microbial action at the actual effluent $\mathrm{pH}$, which was normally in the range of $8.2 \pm 0.1$, was effective yielding COD removal of $77 \%$. Very similar results have been reported with the decolorization study on acid violet 7 by an isolated Pseudomonas strain [9]. Many researchers have studied the 
effect of $\mathrm{pH}$ on decolorization of different textile dyes [10, 11, $12,13]$.The optimal value for better dye waste water treatment is reported to be often a neutral value or slightly alkaline value [8]. Defale et al.[14] reported the optimal $\mathrm{pH}$ range 7.0-8.0 for the removal of remazol Black B by Pseudomonas aeruginosa. Ponraj et al.[15] reported maximum decolorization efficiency $(89.0 \%)$ at $\mathrm{pH} 6.0$ for Pseudomonas sp.

\section{B. Bio Kinetic Modeling}

In order to measure the minimum degradation rate of dye house effluent Pseudomonas stutzeri, the static effluent and $0.62 \mathrm{~g} \mathrm{DCM} / 1$ and $10 \mathrm{ml}$ of growth medium was incubated under anoxic condition at $32{ }^{\circ} \mathrm{C}$ for $48 \mathrm{hr}$. Figure 2 shows the time course of COD remaining.

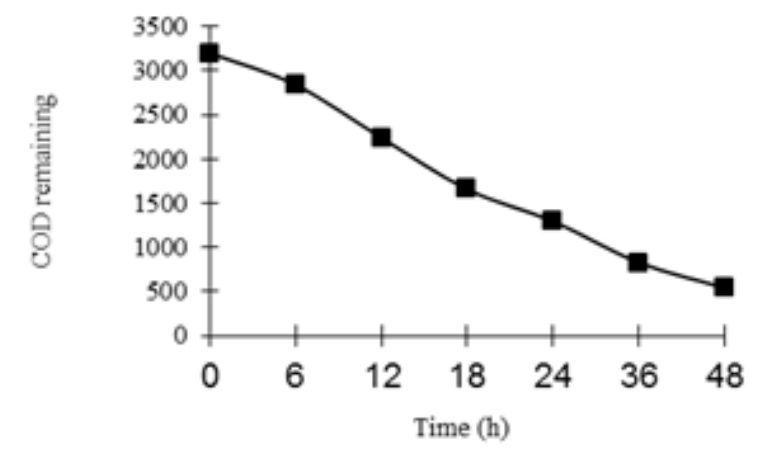

Fig. 2. The time course of degradation of dye house effluent by Pseudomonas stutzeri $\left(\mathrm{t}=48 \mathrm{~h}\right.$; Temp $=32{ }^{\circ} \mathrm{C} ; \mathrm{M}=0.62 \mathrm{~g}$ dry cell mass $)$

$$
v=-\frac{d[S]}{d t}=\frac{V_{m}[S]}{K_{m}+[S]}=\frac{k_{2}\left[E_{0}\right][S]}{k_{-1}+\frac{k_{2}}{k_{1}}+[S]}
$$

The below mentioned Equation 2 gives the convenience on analysis of effect of temperature

$$
\frac{d S}{d t}=-k M^{m} S^{n}
$$

where $t$ is the incubation time (h), $M$ is the biomass concentration (mg DCM/l), $m$ is the partial reaction order with respect to biomass, $S$ is the COD value of the effluent $(\mathrm{mg} / \mathrm{l})$ and $n$ is its partial reaction order. Here, $k$ is the specific COD removal rate with units $\left(\mathrm{mg}^{(1-n)} 1^{(m+n-1)} / \operatorname{mgDCM}^{\mathrm{m}} \mathrm{h}\right)$. It was reported that (2) could be considered as a modified model of Michaelis Menten rate equation (1), when the parameter $K_{m}$ is not included. The relationship between the COD of the effluent and incubation time depending on the partial reaction order (n) is given by

$$
\begin{aligned}
& \left(\frac{S}{S_{0}}\right)^{(1-n)}=1-\frac{(1-n) k M^{m}}{S_{0}^{(1-n)}} t, \text { when }(\mathrm{n} \neq 1) \\
& \left(\frac{S}{S_{0}}\right)=\exp \left(-k M^{m} t\right), \text { when }(\mathrm{n} \neq 1)
\end{aligned}
$$

When the plot between incubation time and the COD value was made, a high degree of linearity was observed $\left(R^{2}>0.99\right)$, as shown in Figure 3. Hence the order of the reaction with respect to effluent COD value was found to be 1.0.

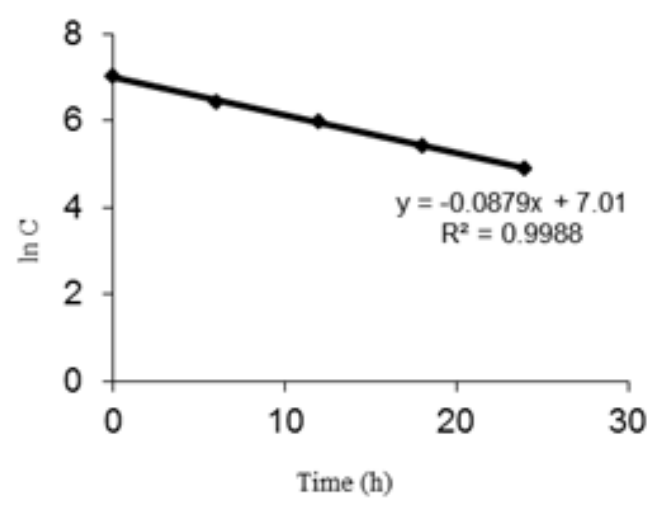

Fig. 3. Data fitting and estimation of Bio Kinetic parameters

For this set of experiments, used to establish a relationship between biomass concentration and effluent COD removal rate, the incubation time was fixed as $12 \mathrm{~h}$. As shown in Figure 4, a linear relationship $\left(\mathrm{R}^{2}>0.97\right)$ was obtained between biomass concentration $M$ and $k M^{m}$ that indicates $m$ equals to unity. Therefore, the COD removal was a first order reaction with respect to biomass concentration $(M)$.

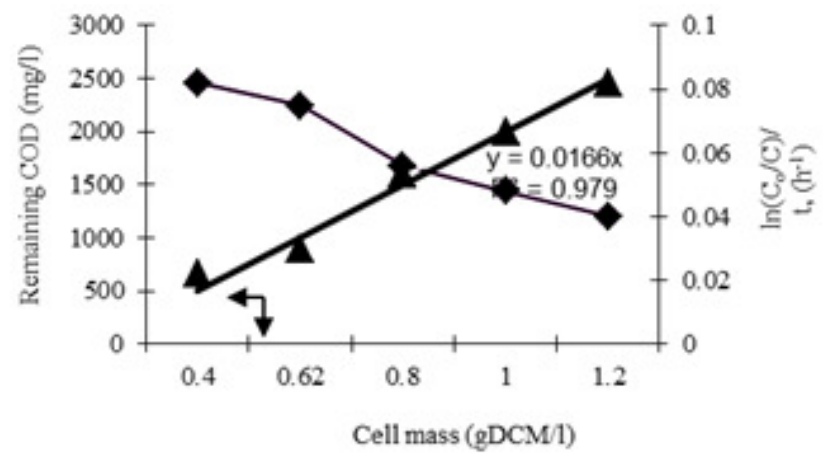

Fig. 4. Effect of cell mass concentration on remaining COD of the effluent at $32{ }^{\circ} \mathrm{C}$

The kinetic model of COD removal by the Pseudomonas stutzeri was given by

$$
\frac{d S}{d t}=-k M S
$$

$$
S=S_{0} \exp (-k M t)
$$

The value of specific COD removal rate, $k$, obtained from the slope of the line in Figure 3 was

$$
k=0.1417 \frac{l}{g D C M h} \text { at } 32^{\circ} \mathrm{C}
$$




\section{CONCLUSION}

1. Effective degradation of dye house effluent was achieved by the bacterial strain Pseudomonas stutzeri under anoxic environment.

2. The optimal $\mathrm{pH}$ for better degradation of dye effluent was found to be 8.0 .

3. The biokinetics of the COD removal was found to be first order with respect to both the microbial concentration and initial COD of the effluent with the rate equation $\frac{d S}{d t}=-0.1417 M S$

4. The specific COD removal rate $(k)$ was found to be $0.1417 \frac{l}{g D C M h}$ at $32^{\circ} \mathrm{C}$.

\section{REFERENCES}

[1] P. Kaushik, A. Malik, "Fungal dye decolourization: recent advances and future potential", Environment International, Vol. 35, No. 1, pp. 127141,2009

[2] K. Chen, J. Wu, D. Liu, S. J. Hwang, "Decolorization of the textile dyes by newly isolated bacterial strains", Journal of Biotechnology, Vol. 101, No. 1, pp. 57-68, 2003

[3] A. Srinivasan, T. Viraraghavan, "Decolorization of dye waste waters by biosorbents: a review", Journal of Environmental Management, Vol. 91, No. 10, pp. 1915-1929, 2010

[4] I. M. Banat, P. Nigam, D. Singh, R. Marchant, "Microbial decolorization of textile dye containing effluents: a review", Bioresource Technology, Vol. 58, No. 3, pp. 217- 227,1996

[5] E. Forgacs, T. Cserhati, G. Oros, "Removal of synthetic dyes from wastewaters: a review", Environment International, Vol. 30, No. 7, pp. 953-971, 2004

[6] J. S. Knapp, P. S. Newby, "The decolourisation of a chemical industry effluent by white rot fungi", Water Research, Vol. 33, No. 2, pp. 575577, 1999

[7] American Public Health Association (APHA), Standard methods for the examination of water and wastewater, $20^{\text {th }}$ ed, American Public Health Association, American Water Works Association, Water Pollution Control Federation, Washington DC, 1998

[8] S. K. Garg, M. Tripathi, S. K. Singh, J. K. Tiwari, "Biodecolorization of textile dye effluent by Pseudomonas putida SKG-1 (MTCC 10510) under the conditions optimized for monoazo dye orange II color removal in simulated minimal salt medium", International Biodeterioration \& Biodegradation, Vol. 74, pp. 24-35, 2012

[9] J. Yu, X. Wang, P. L. Yue, "Optimal decolorization and kinetic modelling of synthetic dyes by pseudomonas strains", Water Research Vol. 35, No. 15, pp. 3579-3586, 2001

[10] O. D. Olukanni, A. Osuntoki, G. O. Gbenle, "Decolorisation of azo dyes by a strain of micrococcus isolated from a reuse dump soil", Biotechnology, Vol. 8, pp. 442-448, 2009

[11] R. G. Saratale, G. D. Saratale, D. C. Kalayani, J. S. Chang, S. P. Govindwar, "Enhanced decolorization and biodegradation of textile azo dye Scarlet $\mathrm{R}$ by using developed microbial consortium-GR", Bioresource Technology, Vol. 100, No. 9, pp. 2493-2500, 2009

[12] R. Sawney, A. Kumar, "Congo red (azo dye) decolourization of local isolate VT-II inhabiting dye-effluent exposed soil", International Journal of Environmental Sciences, Vol. 1, No. 6, pp. 1261-1267, 2011

[13] H. Wang, J. Q. Su, X. W. Zheng, Y. Tian, X. J. Xiong, T. L. Zheng, "Bacterial decolorization and degradation of the reactive dye Reactive Red 180 by Citrobacter sp. CK3", International Biodeterioration \& Biodegradation, Vol. 63, pp. 395-399, 2009
[14] N. Dafale, S. Wate, S. Meshram, T. Nandy, "Kinetic study approach of remazol black- B for the development of two-stage anoxic reactor for decolorization/biodegradation of azo dyes by activated bacterial consortium", Journal of Hazardous Materials, Vol. 159, No. 2-3, pp. 319-328, 2008

[15] M. Ponraj, K. Gokila, V. Zambare, "Bacterial decolorization of textile dye-Orange 3R", International Journal of Advanced Biotechnology and Research, Vol. 2, No. 1, pp. 168-177, 2011 